\title{
The Role of Trace Metals and Environmental Factors in the Onset and Progression of Schizophrenia in Pakistani Population
}

\author{
Rukhsana Nawaz', Erum Zahir ${ }^{2}$, Sonia Siddiqui' ${ }^{1}$, Asad Usmani ${ }^{3}$, K. Fatima Shad ${ }^{*}$ \\ ${ }^{1}$ Dr. Panjwani Center for Molecular Medicine and Drug Research, ICCBS, University of Karachi, Karachi, Pakistan \\ ${ }^{2}$ Department of Chemistry, University of Karachi, Karachi, Pakistan \\ ${ }^{3}$ AnylabTest, Everett, WA, USA \\ ${ }^{4}$ School of Medical and Molecular Biosciences, Faculty of Science, University of Technology, Sydney, Australia \\ Email: ${ }^{*}$ ftmshad@gmail.com
}

Received 1 October 2014; revised 3 November 2014; accepted 20 November 2014

Copyright (C) 2014 by authors and Scientific Research Publishing Inc.

This work is licensed under the Creative Commons Attribution International License (CC BY).

http://creativecommons.org/licenses/by/4.0/

(c) () Open Access

\begin{abstract}
Exposure to toxic chemicals appears to be one of the major factors in the onset of Schizophrenia. Present study was designed to find out the association of socio-economic, clinical and heavy metals such as chromium $(\mathrm{Cr})$, lead $(\mathrm{Pb})$ copper $(\mathrm{Cu})$, zinc $(\mathrm{Zn})$, iron $(\mathrm{Fe})$, manganese $(\mathrm{Mn})$ selenium (Se) and arsenic (As) as the principle environmental factors that appear to impact schizophrenic condition in Pakistani population. In this study we have tried to expose some factors such as drug abuse, marital status, education, monthly income that could be related to the disease. These parameters were not investigated before in Pakistani subjects. A self-made questionnaire was developed to collect and record the history of patient's social and economical status. The level of transition metals in the whole blood was also measured by using Inductive couple plasma optical emission spectroscopy (ICP-OES). Present study has found higher levels of $\mathrm{Cr}, \mathrm{Pb}, \mathrm{Zn}, \mathrm{Se}, \mathrm{As}$ and $\mathrm{Cu}$ and lower levels of Fe and Mn in the blood of newly diagnosed (ND) patients when compared to the controls. While comparing ND with the patients who were on medication (Old Diagnosed) we, found lower level of these metals except for copper in ND. However no significant differences were observed between any trace metal levels between the studied groups. The survey concludes that economic status, marital status and illegal drugs are significantly associated with schizophrenia. Pakistani men who use cannabis are significantly higher in numbers when compared to women in acquiring the psychiatric symptoms.
\end{abstract}

\section{Keywords}

Schizophrenia, Trace Metals, Pakistani Population, Inductive Couple Plasma Optical Emission

\footnotetext{
"Corresponding author.
}

How to cite this paper: Nawaz, R., Zahir, E., Siddiqui, S., Usmani, A. and Fatima Shad, K. (2014) The Role of Trace Metals and Environmental Factors in the Onset and Progression of Schizophrenia in Pakistani Population. World Journal of Neuroscience, 4, 450-460. http://dx.doi.org/10.4236/wjns.2014.45051 


\section{Spectroscopy (ICP-OES), Human}

\section{Introduction}

Schizophrenia is a Greek Word meaning split mind. It is a psychiatric diagnosis that describes a mental disorder characterized by impaired judgment, behavior and an inability to interpret reality. It affects approximately $1 \%$ of the total world population where as in Pakistan 1.5\% of population is enduring from this ailment [1]. The frequency of affecting men and women is equal, but in some cases it has been noticed onset is often later in women than in men and the onset usually occurs between the ages of 15 - 40 years. Major factors like unemployment, living standard, Patient's sex, age, education, marital and economic status, age at onset and duration of illness, degree of disability, clinical symptoms and cost of treatment are common obstacles in Pakistan. Among all other factors metals are also poses a threat to the people who are exposed to these metals quite enough along with other socio-economic problems. Metals are essential for many metabolic and biochemical processes for example copper (Cu), Iron (Fe), Zinc (Zn) and Manganese (Mn) catalyze redox reactions that are significantly involved in cellular respiration, metabolism, chemical detoxification, and neurotransmitter synthesis [2]. These all are essential trace metals required for the optimal function of central nervous function (CNS) as these metals act as catalyst, second messengers and regulators of gene expression. In humans metals entered through food, water, air, or absorption through the skin. These metals reached the brain via BBB [3]. Heavy metal toxicity can result in damaged or reduced mental and CNS, lower energy levels, and damage to blood composition [4]. Previous studies indicated that the serum levels of copper, selenium, and zinc were altered probably by some immunocytokines as a defense response against rheumatoid arthritis [5]. On the other hand, heavy metal toxicity can result in damaged or reduced mental and CNS functions. Chronic exposure of metals causes the symptoms like impaired cognitive, motor, and language skills; learning difficulties; nervousness and emotional instability.

Recent research established an association between DNA methylation and environmental metals [6]. They appear to induce alterations on the DNA methylation metabolism (epigenetic) by which they initiate the cascade of events including gene specific DNA hypo- vs hyper-methylation. DNA hypo- vs hyper-methylation causes aberrant changes in genes expression pattern during neurodevelopment [7]. Zinc is one of the most prevalent trace elements found in the hippocampus and cause the impairment in learning and memory [8]. It can also be considered as a neurotransmitter because of its accumulation in presynaptic vesicles during excitation, where it is released and interact with some ionotropic receptors such as AMPA kainate, NMDA and GABA receptors [9]. Similarly abnormal concentrations of manganese in the brain, especially in the basal ganglia, are associated with neurological disorders similar to Parkinson's disease [10]. High levels of $\mathrm{Mn}$ in blood can cause the compulsive behavior emotional liability and hallucinations [11]. Moreover $\mathrm{Pb}$ is present in paints, dust, water, soil and it can produce neurotoxic side effects, leading to other risk factors, such as aggressive behavior, hypertension [12]. Trace metal Se play significant role in the maintenance of proper functioning of the CNS and insufficient level of Se causes the neurodegenerative conditions [13]. According to the epidemiological studies neurotoxicity is associated with arsenic (As), exposure via drinking water [14] [15]. Fe is an essential co factor for many proteins that are involved in the normal function of neuronal tissues for example tyrosine hydroxylase enzyme contain non haem iron which is required for the synthesis of dopamine. However, increase in iron accumulation in the brain can cause a range of disorder of CNS [16]. Copper is found in nuts; beans; chocolate etc. and stimulate the production of the neurotransmitters epinephrine, nor epinephrine and dopamine. An imbalance of copper can cause fatigue, insomnia, depression. In present study the possible involvement of socio-economic factors and heavy metals in mental deficit was investigated. It is a known fact that metal ions are fundamental for several life processes and a slight alteration in their activity could cause severe diseases.

\section{Material and Methods}

\subsection{Data Collection}

Appropriate questionnaire was developed as to obtain personal information and to identify factors responsible for the onset of Schizophrenia. All patients selected for sampling were first asked to read and understand the consent form with the help of their attendant and sign before taking the samples. Total diagnosed Schizophrenic 
subjects were 35 with the age range between 15 - 50 years for males and 12 - 59 years for females with 20 siblings as controls. All the subjects were Pakistanis. Schizophrenic patients were divided into two groups. First group contain 23 patients who were on antipsychotic drugs (old diagnosed) and second group contain 12 newly diagnosed (ND) patients. The ND patients are also schizophrenics but they were being just diagnosed and were not on medication. However they were addicted to drugs such as cannabis, tobacco, hashish, alcohol and betel nut. The study was approved by the Human Ethics Committee of Jinnah postgraduate medical center (JPMC), Karachi, Pakistan with the ethic number of F.2-81/2008-GENL/2128/JPMC.

\subsection{Survey Questionnaire}

Appropriate self made questionnaire was developed as to obtain personal information and to identify many socio-economic factors that could be responsible for the onset of schizophrenia. All patients were clinically evaluated by expert psychiatrists by taking the history and clinical examinations. Patients self assessment survey was done by government hospitals and some private hospitals situated in Karachi, Pakistan.

\subsection{Sample Collection}

Blood samples were collected from Schizophrenic patients and their control (sibling). These patients were diagnosed according to the DSM-IV and ICD-10 criteria and were admitted to the psychiatric wards of Jinnah postgraduate medical center and Civil Government Hospital, Karachi, Pakistan. $5 \mathrm{ml}$ blood samples were collected from each subject (patients and controls) into metal free plastic tubes containing heparin.

\subsection{Wet acid Digestion}

For digestion of biological samples of patients and controlled subjects of human whole blood were directly taken into Pyrex flasks separately, added $5 \mathrm{ml}$ whole blood was mixed into digestion acid of a freshly prepared mixture of concentrated $\mathrm{HNO}_{3}-\mathrm{H}_{2} \mathrm{O}_{2}(2: 1, \mathrm{v} / \mathrm{v})$ digested at $60^{\circ} \mathrm{C}-70^{\circ} \mathrm{C}$ for $1-2 \mathrm{~h}$. The digests were then treated with $2 \mathrm{ml}$ nitric acid and few drops of $\mathrm{H}_{2} \mathrm{O}_{2}$, heated on hot plate about $80^{\circ} \mathrm{C}$ until the clear digested solution was obtained, the excess acid mixture was evaporated to semidried mass, cooled and diluted with $0.1 \mathrm{~mol} / \mathrm{l}$ nitric acid. Once the beaker was cooled then the content was diluted with de-ionized water up to $50 \mathrm{ml}$ volume.

\subsection{Inductively Coupled Plasma Optical Emission Spectrometer (ICP-OES)}

It is a very sensitive technique of mass spectrometry which is capable of detecting metals and several non-metals at concentrations as low as one part in $10^{6}$ (part per million) (Table 1). ICP-OES has greater speed, precision, and sensitivity than Atomic Absorption (AA) Technique. We have used inductively coupled plasma optical emission spectrometer (ICP-710-OES version, that is UKAS approved QC material ordered from (MERCK Germany) for the determination of trace metals of interest in the Central Laboratories Unit, Research Affairs, at the UAE University. Element standards $(0.01,0.1,1.0,10.0,50.0 \mathrm{mg} / \mathrm{L})$ are commercially available or prepared per instrument manufacture recommendations. Standard Argon and compressed Nitrogen gas was used supplied by Emirates Gas Company, Dubai.

\subsection{QC/QA}

Standard solutions of heavy metals were provided by Merck (Darmstadt, Germany). The standards were prepared from the individual $1000 \mathrm{mg} / \mathrm{l}$ standards (Merck), in $0.1 \mathrm{M} \mathrm{HNO}_{3}$. Working standards were prepared from the stock solutions. Quality assurance (QA) and quality control (QC) procedures were strictly followed throughout the present study. The level of accuracy and QC for the determination of heavy metal concentrations was comprised of measurements of natural matrix Certified Reference Material (CRM) and the measurements of duplicates for each batch of samples. NIST standard 1573 was used for the evaluation of procedures. Reproducibility of the measurements for the metals ranged between 92.3 and 113 percentage relative standard deviation (\%RSDs). RSD is generally better than $5 \%$ if an analyte concentration is about 10 times higher than the relevant limit of detection. The mean recovery for certified reference material (CRM 1573) was below 8.7\% whereas the percent recovery of RSD for duplicate samples were less than 9\%. Student's t-test and chi square was carried out for statistical analysis with the program SPSS version 17 for windows (Table 1). 
Table 1. Statistical analysis were done by using SPSS version 17 for Windows.

\begin{tabular}{|c|c|c|c|c|}
\hline \multicolumn{5}{|c|}{ ICP-MS parameters } \\
\hline \multicolumn{5}{|c|}{ Analysis lines } \\
\hline Elements & Wavelength & Types & PPP & Atomic weight \\
\hline $\mathrm{Cu}$ & 324.754 & Analyte & 2 & 63.54 \\
\hline $\mathrm{Mn}$ & 257.610 & Analyte & 2 & 54.94 \\
\hline $\mathrm{Pb}$ & 220.353 & Analyte & 2 & 207.19 \\
\hline $\mathrm{Zn}$ & 206.200 & Analyte & 2 & 65.57 \\
\hline $\mathrm{Fe}$ & 238.204 & Analyte & 2 & 55.85 \\
\hline $\mathrm{Cr}$ & 267.716 & Analyte & 2 & 52.00 \\
\hline Se & 196.09 & Analyte & 2 & 78.96 \\
\hline As & 189.04 & Analyte & 2 & 74.92 \\
\hline \multicolumn{5}{|l|}{ Conditions set } \\
\hline \multicolumn{2}{|c|}{ Power (Kw) } & \multicolumn{3}{|c|}{1.20} \\
\hline \multicolumn{2}{|c|}{ Plas flow (L/min) } & & \multicolumn{2}{|c|}{15.0} \\
\hline \multicolumn{3}{|c|}{ Aux flow (L/min) } & \multicolumn{2}{|c|}{1.50} \\
\hline \multicolumn{3}{|c|}{ Neb flow (L/min) } & \multicolumn{2}{|c|}{0.75} \\
\hline \multicolumn{3}{|c|}{ Replicate times (s) } & \multicolumn{2}{|c|}{5.000} \\
\hline \multicolumn{3}{|c|}{ Stab range (s) } & \multicolumn{2}{|c|}{10} \\
\hline \multicolumn{3}{|c|}{ Sample uptake (s) } & \multicolumn{2}{|c|}{7} \\
\hline \multicolumn{3}{|c|}{ Rinse time (s) } & \multicolumn{2}{|c|}{10} \\
\hline \multicolumn{3}{|c|}{ Pump rate (rpm) } & \multicolumn{2}{|c|}{30} \\
\hline \multicolumn{3}{|c|}{ Fast pump } & \multicolumn{2}{|c|}{ On } \\
\hline \multicolumn{5}{|c|}{ Calibration setting } \\
\hline \multicolumn{3}{|c|}{ Calibration Mode } & \multicolumn{2}{|c|}{ Quantitative } \\
\hline \multicolumn{3}{|c|}{ No. Standard } & \multicolumn{2}{|c|}{5} \\
\hline \multicolumn{3}{|c|}{ Corr Coeff Limit } & \multicolumn{2}{|c|}{0.995000} \\
\hline \multicolumn{5}{|c|}{ Standard concentration for each metal } \\
\hline & dard 1 & & & \\
\hline & dard 2 & & & \\
\hline & dard 3 & & & \\
\hline & dard 4 & & & \\
\hline & dard 5 & & & \\
\hline
\end{tabular}

\subsection{Statistical Analysis}

SPSS software version 17 was used for the analysis of the data. The results were expressed as Means \pm SD by using SPSS software. Students paired $t$ test were performed for the determination of difference between group means. The significance level was set as $\mathrm{p}<0.05$. Chi square was also carried out to determine the association of socio-economic factors such as marital status, education, age, and residential area to the levels of trace metals in Schizophrenic patients.

\section{Results}

\subsection{Socio-Economic, Environmental and Clinical Factors}

According to our questionnaire all participants were living in the nearby vicinity of the same city i.e. Karachi, though they were from different ethnic background. The socio-demographic and clinical characteristics were compared between schizophrenic male and female patients (Table 2). Out of 140 participants 80 were females and 60 were male patients. All groups were matched for mean age, age at contact, gender and clinical symptoms. 
Table 2. Effects of socio-chemical factors on the onset of Schizophrenia.

\begin{tabular}{|c|c|c|c|c|c|}
\hline Variables & Males $(n=60)$ & Females $(n=80)$ & df & t value & $P$ values \\
\hline \multirow[t]{2}{*}{ Age } & 15 - 50 years & 12 - 59 years & & & \\
\hline & & Age at onset & & & \\
\hline \multirow[t]{2}{*}{ Mean \pm SD } & $25.09 \pm 7.11$ & $23.9 \pm 8.64$ & 137 & 0.85 & NS \\
\hline & & Age at contact & & & \\
\hline Mean \pm SD & $29.1 \pm 8.7$ & $27.43 \pm 10.33$ & 138 & 1.01 & NS \\
\hline \multirow[t]{2}{*}{ Variables } & Males $(n=60)$ & Females $(n=80)$ & df & $\mathrm{X}^{2}$ value & $P$ values \\
\hline & & Marital status & & & \\
\hline Single & $53.3 \%(32)$ & $33.75 \%$ (27) & \multirow{4}{*}{3} & \multirow{4}{*}{9.98} & \multirow{4}{*}{${ }^{* *} 0.01$} \\
\hline Married & $45 \%(27)$ & $51.25 \%(41)$ & & & \\
\hline Divorced & $1.6 \%(1)$ & $13.75 \%$ (11) & & & \\
\hline \multirow[t]{2}{*}{ Widow } & No & $1.25 \%(1)$ & & & \\
\hline & & Education & \multirow{6}{*}{3} & \multirow{6}{*}{2.18} & \multirow{6}{*}{ NS } \\
\hline Nil & $20 \%(12)$ & $25 \%(20)$ & & & \\
\hline School Grade ( 5-10) & 63.33\% (38) & $58.75 \%(47)$ & & & \\
\hline College (11-14) & $16.66 \%(10)$ & $13.75 \%(11)$ & & & \\
\hline \multirow[t]{2}{*}{ University } & $0 \%$ & $2.5 \%(2)$ & & & \\
\hline & & Salary bracket & & & \\
\hline Lower & $53.3 \%(32)$ & $43.75 \%$ (35) & \multirow{3}{*}{2} & \multirow{3}{*}{7.42} & \multirow{3}{*}{${ }^{*} 0.02$} \\
\hline Middle & $46.66 \%$ (28) & $45 \%(36)$ & & & \\
\hline \multirow[t]{2}{*}{ Upper } & $0 \%$ & $11.25 \%(9)$ & & & \\
\hline & & Symptoms & \multirow{4}{*}{1} & \multirow{4}{*}{3.47} & \multirow{4}{*}{ NS } \\
\hline & $78 \%(47)$ & $63.75 \%$ (51) & & & \\
\hline \multirow{2}{*}{ Positive } & $21.6 \%(13)$ & $36.25 \%$ (29) & & & \\
\hline & & Drug abuse & & & \\
\hline Cannabis & $16.6 \%(10)$ & $2.5 \%(2)$ & \multirow{5}{*}{5} & \multirow{5}{*}{34.83} & \multirow{5}{*}{${ }^{* * * *} 0.00000162$} \\
\hline Tobacco & $36.66 \%(22)$ & 18.75\% (15) & & & \\
\hline Charas & $15 \%(9)$ & $2.5 \%(2)$ & & & \\
\hline Alcohol & $13.33 \%(8)$ & 13.75\% (11) & & & \\
\hline Betel Nut & $10 \%(6)$ & $25 \%(20)$ & & & \\
\hline
\end{tabular}

Table shows highly associated risk factors of Schizophrenia between male and female patients. The data did not find significant differences at the time of onset between males and females. Similarly, no significant correlation of the disease was found with the level of education and awareness and symptoms type. Effects of education, monthly income and drug abuse were found significantly associated with schizophrenia. SD = Standard Deviation; $\mathrm{df}=$ Degree of Freedom; ${ }^{*} \mathrm{p}=0.03,{ }^{* *} \mathrm{p}=0.01,{ }^{* * * *} \mathrm{p}=0.000001 ; \mathrm{NS}=$ Not Significant; $\mathrm{t} / \mathrm{x}^{2}=$ Chi Square; $\mathrm{n}=$ Number of patients male or female

Our data shows no significant difference in the onset of disease between the genders and the mean age of the groups i.e. from 12 - 59 years. There were no significant differences found to be present between the ages of onset and contact among the groups. This shows that males and females are equally prone to have schizophrenia. Moreover men and women of ages between 12 - 59 years were equally susceptible and can develop schizophrenic symptoms. Interestingly there was a slight non-significant difference $\left(x^{2}=3.472, p=0.06\right)$ found between positive and negative symptoms only in between the genders. It was found that $78 \%$ of men shows a negative and 36.25\% women shows positive symptoms of schizophrenia (Table 2). Similarly, no significant correlation of the disease was found with the level of education and awareness.

According to our survey all Pakistani Schizophrenic subjects have completed their primary or secondary education except for $2.5 \%$ of the effected population that has reached up to the university level. In Pakistani population we have observed that single men and married or divorced women have significantly higher tendency to develop schizophrenia (Table 2). Whereas in men with lower income and females with higher incomes shows a significant $\left(X^{2}=7.47 ; \mathrm{p}<0.05\right)$ correlation with the disease. Present data recommends a major role of drugs and other addictives such as Cannabis, Charas, Alcohol, Tobacco and Betel nut in the onset of schizophrenia. According to our survey $16 \%$ men uses cannabis and $36.6 \%$ men are addictive to tobacco and alcohol, in contrast to this $25 \%$ of women are addictive to betel nut. Our results demonstrate that male schizophrenic patients are using more illicit drugs as compare to their female counterparts. 


\subsection{Trace Metal Levels in Pakistani Schizophrenic Population}

Trace elements are directly involved in human metabolism and there is a growing interest in the role of certain elements in physiological and psychological processes. The level of trace metals such as $\mathrm{Cr}, \mathrm{Pb}, \mathrm{Zn}, \mathrm{Cu}, \mathrm{Fe}$, Se, As and Mn have been detected in ppm (mg/L) in blood samples of Pakistani Schizophrenic patients (Table 2) by using inductive couple plasma-optical emission spectrometry (ICP-OES). ICP-OES is the most reliable and the only technique available which can provide the correct levels of these metals even if they are present in trace amounts $(<5 \mathrm{ppm})$. We have used this method not only to obtain the trace metal levels in both male and female patients but also to compare the iron levels between both genders (Figure 1). ICP-OES used in a clinical laboratory for a variety of specimens, including whole blood, serum, hair and urine [17]. Trace level values are typically defined $<5 \mathrm{mg} / \mathrm{dL}$ [18]. Current study did not find any significant differences between the levels of trace metals in any group (Control, Newly diagnosed and Old diagnosed). We also did not observed significant any decrease or increase in the levels of any trace metals in newly diagnosed and medicated-schizophrenic patients when compared to controls (Table 3). The present results showed that these toxic metals were not significantly involved in the progression and onset of schizophrenia at least in Pakistani population.

When we compared individual values of trace metals in male and female Schizophrenic patients, we found higher values of $\mathrm{Cr}, \mathrm{Pb}, \mathrm{Fe}$ and $\mathrm{Mn}$ in males while $\mathrm{Zn}$ and $\mathrm{Cu}$ in females (Table 4(a) and Table 4(b)). While comparing male patients with their controls we found that in newly diagnosed patient the levels of all trace metals were higher except for Fe. Similarly, for females all trace metal values were higher in newly diagnosed patients except for Fe and Mn.
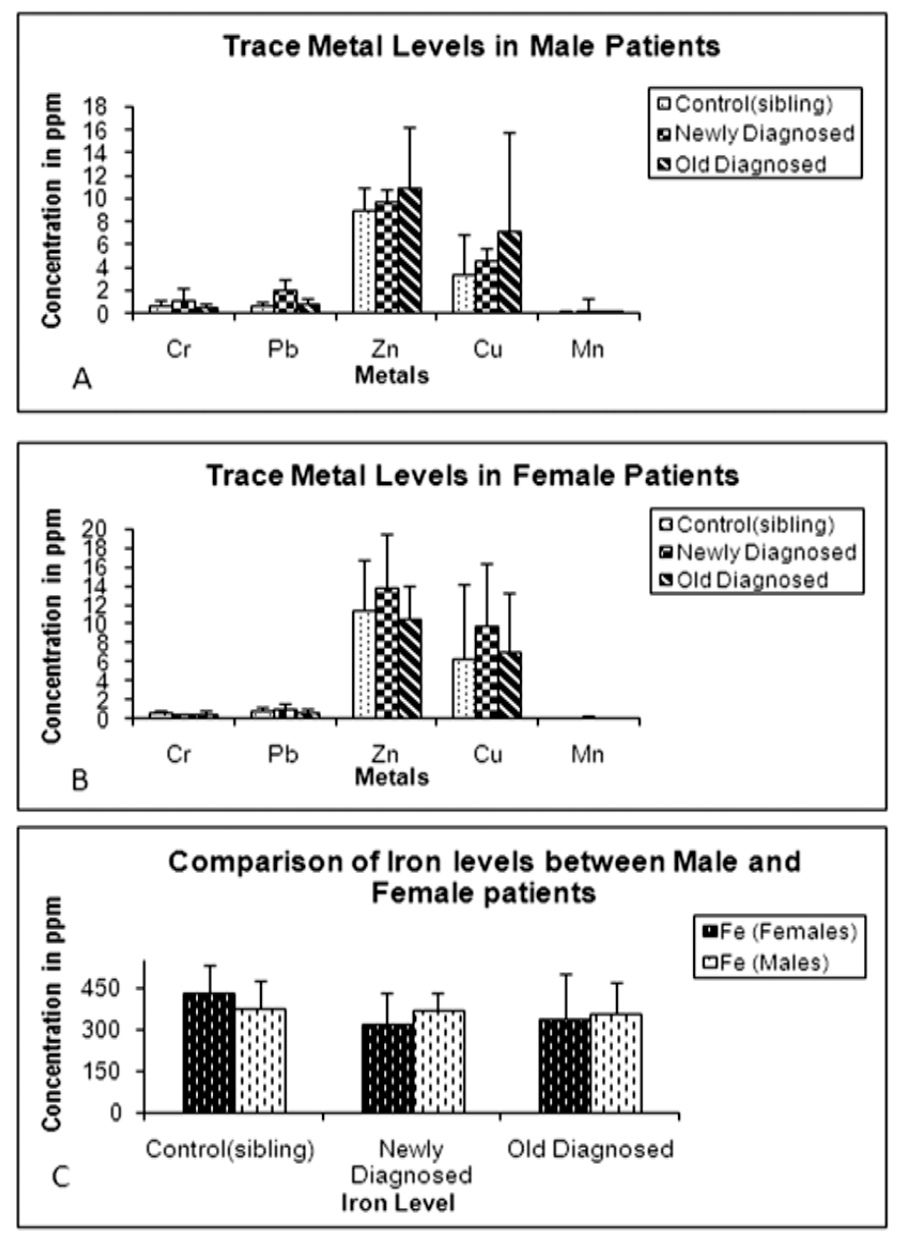

Figure 1. Heavy metals levels in the blood of Schizophrenic patients from Pakistan. Comparison of trace metals levels between male and female schizophrenic patients and control group. 
Table 3. Trace metals level in the case-control study.

\begin{tabular}{|c|c|c|c|c|c|c|c|c|}
\hline Patients & Cr (ppm) & Pb (ppm) & Zn (ppm) & Cu ((ppm) & Fe (ppm) & Mn (ppm) & Se (ppm) & As (ppm) \\
\hline \multicolumn{9}{|c|}{ Newly Diagnosed $(n=12)$} \\
\hline Mean \pm SD & $0.98 \pm 1.25$ & $1.80 \pm 2.90$ & $10.80 \pm 3.83$ & $5.99 \pm 5.38$ & $360.97 \pm 74.60$ & $0.21 \pm 0.18$ & $0.56 \pm 0.29$ & $0.23 \pm 0.19$ \\
\hline \multicolumn{9}{|c|}{ Old Diagnosed $(n=22)$} \\
\hline Mean \pm SD & $0.51 \pm 0.30$ & $0.75 \pm 0.37$ & $10.73 \pm 4.52$ & $7.21 \pm 7.36$ & $353.19 \pm 133.47$ & $0.14 \pm 0.06$ & $0.49 \pm 0.22$ & $0.24 \pm 0.21$ \\
\hline \multicolumn{9}{|c|}{ Control $(n=19)$} \\
\hline Mean \pm SD & $0.70 \pm 0.45$ & $0.70 \pm 0.40$ & $9.69 \pm 3.45$ & $4.36 \pm 5.20$ & $393.08 \pm 102.76$ & $0.17 \pm 0.12$ & $0.49 \pm 0.22$ & $0.2 \pm 0.19$ \\
\hline $\begin{array}{l}{ }^{a} \text { t-value } \\
\text { p-value }\end{array}$ & $\begin{array}{l}0.913 \\
0.369\end{array}$ & $\begin{array}{l}1.643 \\
0.111\end{array}$ & $\begin{array}{l}0.837 \\
0.409\end{array}$ & $\begin{array}{l}0.836 \\
0.410\end{array}$ & $\begin{array}{l}0.935 \\
0.358\end{array}$ & $\begin{array}{l}0.721 \\
0.477\end{array}$ & $\begin{array}{l}0.69 \\
0.49\end{array}$ & $\begin{array}{l}0.21 \\
0.83\end{array}$ \\
\hline $\begin{array}{l}{ }^{b} \text { t-value } \\
\text { p-value }\end{array}$ & $\begin{array}{l}1.584 \\
0.121\end{array}$ & $\begin{array}{l}0.409 \\
0.685\end{array}$ & $\begin{array}{l}0.818 \\
0.418\end{array}$ & $\begin{array}{l}1.410 \\
0.167\end{array}$ & $\begin{array}{l}1.059 \\
0.296\end{array}$ & $\begin{array}{l}1.143 \\
0.260\end{array}$ & $\begin{array}{l}0.83 \\
0.41\end{array}$ & $\begin{array}{l}0.47 \\
0.63\end{array}$ \\
\hline $\begin{array}{l}{ }^{c} \text { t-value } \\
\text { p-value }\end{array}$ & $\begin{array}{l}1.702 \\
0.089\end{array}$ & $\begin{array}{c}1.693 \\
0.10\end{array}$ & $\begin{array}{l}0.045 \\
0.964\end{array}$ & $\begin{array}{l}0.506 \\
0.617\end{array}$ & $\begin{array}{l}0.186 \\
0.854\end{array}$ & $\begin{array}{l}1.713 \\
0.96\end{array}$ & $\begin{array}{l}1.36 \\
0.18\end{array}$ & $\begin{array}{l}0.16 \\
0.86\end{array}$ \\
\hline
\end{tabular}

Clearly demonstrates that the levels of trace metals were not significantly different in both groups of schizophrenic patients when compared with the controls. ${ }^{a}$ Control when compared to newly diagnosed , ${ }^{b}$ Control when compared to old diagnosed, ${ }^{\mathrm{c}}$ Newly diagnosed when compared to old diagnosed, $\mathrm{SD}=$ Standard Deviation, $\mathrm{n}=$ number of patients, $\mathrm{Ppm}=$ part per million.

Table 4. The minimum and maximum trace level of metals level in Pakistani Females (a) \& Males (b)

(a)

\begin{tabular}{|c|c|c|c|c|c|c|c|c|}
\hline Females Patients & Cr (ppm) & Pb (ppm) & Zn (ppm) & Cu (ppm) & Fe (ppm) & Mn (ppm) & Se (ppm) & As (ppm) \\
\hline \multicolumn{9}{|c|}{ Control $(n=6)$} \\
\hline Mean \pm SD & $0.69 \pm 0.27$ & $0.81 \pm 0.36$ & $11.3 \pm 5.36$ & $6.38 \pm 7.89$ & $431.45 \pm 102.24$ & $0.11 \pm 0.01$ & $0.49 \pm 0.25$ & $0.25 \pm 0.27$ \\
\hline Minimum & 0.22 & 0.47 & 7.09 & 0.93 & 292.89 & 0.10 & 0.12 & 0.01 \\
\hline Maximum & 1.26 & 1.32 & 21.77 & 18.64 & 554.70 & 0.14 & 0.81 & 0.78 \\
\hline \multicolumn{9}{|c|}{ Newly Diagnosed $(n=3)$} \\
\hline Mean \pm SD & $0.49 \pm 0.11$ & $1.128 \pm 0.46$ & $13.88 \pm 5.52$ & $9.89 \pm 6.42$ & $321.09 \pm 110.66$ & $0.11 \pm 0.01$ & $0.52 \pm 0.25$ & $0.11 \pm 0.06$ \\
\hline Minimum & 0.39 & 0.79 & 8.55 & 2.53 & 209.03 & 0.10 & 0.37 & 0.13 \\
\hline Maximum & 0.62 & 1.66 & 19.57 & 14.31 & 430.30 & 0.55 & 0.82 & 0.34 \\
\hline \multicolumn{9}{|c|}{ Old Diagnosed $(n=10)$} \\
\hline Mean \pm S.D & $0.53 \pm 0.32$ & $0.71 \pm 0.27$ & $10.49 \pm 3.57$ & $7.17 \pm 6.04$ & $343.15 \pm 162.36$ & $0.14 \pm 0.05$ & $0.47 \pm 0.23$ & $0.24 \pm 0.15$ \\
\hline Minimum & 0.22 & 0.24 & 5.88 & 0.94 & 95.48 & 0.08 & 0.18 & 0.05 \\
\hline Maximum & 1.29 & 1.24 & 19.00 & 19.36 & 608.65 & 0.22 & 0.76 & 0.61 \\
\hline
\end{tabular}

Data compared individual values of trace metals in female and found higher values of $\mathrm{Zn}$, and $\mathrm{Cu}$ in female patients. $\mathrm{SD}=\mathrm{Standard} \mathrm{Deviation}$, $\mathrm{n}=$ number of patients, ppm = part per million.

(b)

\begin{tabular}{|c|c|c|c|c|c|c|c|c|}
\hline Male Patients & Cr (ppm) & Pb (ppm) & Zn (ppm) & Cu (ppm) & $\mathrm{Fe}(\mathrm{ppm})$ & Mn (ppm) & Se (ppm) & As (ppm) \\
\hline \multicolumn{9}{|c|}{ Control $(n=6)$} \\
\hline Mean \pm SD & $0.70 \pm 0.49$ & $0.65 \pm 0.42$ & $8.92 \pm 1.97$ & $3.43 \pm 3.41$ & $375.37 \pm 102.02$ & $0.15 \pm 0.09$ & $0.49 \pm 0.22$ & $0.24 \pm 0.19$ \\
\hline Minimum & 0.13 & 0.17 & 6.56 & 0.86 & 168.89 & 0.07 & 0.13 & 0.04 \\
\hline Maximum & 1.65 & 1.67 & 12.72 & 12.07 & 535.21 & 0.44 & 0.84 & 0.79 \\
\hline \multicolumn{9}{|c|}{ Newly Diagnosed $(n=3)$} \\
\hline Mean \pm SD & $1.15 \pm 1.42$ & $2.03 \pm 3.36$ & $9.78 \pm 2.80$ & $4.69 \pm 4.68$ & $374.26 \pm 61.87$ & $0.24 \pm 0.20$ & $0.57 \pm 0.32$ & $0.23 \pm 0.22$ \\
\hline Minimum & 0.34 & 0.45 & 6.25 & 0.86 & 281.92 & 0.09 & 0.08 & 0.03 \\
\hline Maximum & 4.86 & 10.90 & 13.75 & 14.47 & 489.48 & 134.13 & 1.05 & 0.73 \\
\hline \multicolumn{9}{|c|}{ Old Diagnosed $(n=10)$} \\
\hline Mean \pm SD & $0.49 \pm 0.30$ & $0.78 \pm 0.45$ & $10.93 \pm 5.34$ & $7.25 \pm 8.58$ & $361.15 \pm 110.79$ & $0.24 \pm 0.20$ & $0.40 \pm 0.23$ & $0.20 \pm 0.15$ \\
\hline Minimum & 0.17 & 0.25 & 4.95 & 0.65 & 165.35 & 0.10 & 0.04 & 0.03 \\
\hline Maximum & 1.29 & 1.80 & 21.80 & 23.92 & 509.10 & 0.76 & 0.78 & 0.54 \\
\hline
\end{tabular}

Data showing the comparison of individual values of trace metals levels in male patients among three groups. We found higher values of $\mathrm{Cr}$, $\mathrm{Pb}$, and $\mathrm{Mn}$ in male patients. SD = Standard Deviation, $\mathrm{n}=$ number of patients, $\mathrm{ppm}=$ part per million. 


\section{Discussion}

\subsection{Association of Environmental and Socio-Economical Factors in the Onset of Schizophrenia in Pakistani Population}

In Pakistan 1.5\% of the population is suffering from Schizophrenia and its prevalence is higher because of the poor care and un-acceptance of disorder. Their families believed in Shamans (Aamil/Peer) for the treatment which usually makes their conditions worse. Major factors like unemployment, living standard, education, marital status, economic status and cost of treatment play significant roles for the onset of schizophrenia in Pakistan. In this study we identified factors such as drug abuse, marital status, education, monthly income that are related with Schizophrenia. Likewise the levels of trace metals observed in the controls and patients were directing some clues for the disease.

According to our survey females are more affected than men (Table 2). Previous finding showed that many women became schizophrenics or acquired mood disorder illnesses after or during pregnancy, delivery or nursing [19]. This could be explained by considering possibilities of postpartum depression in which the level of amino acid tryptophan, the main precursor for serotonin, is decreased leading to low serotonin levels which leads which lead to depression [20]. Furthermore evidences have suggested estrogen hormone is involved in memory and cognition function so any imbalances in its levels might affect the mother or its unborn child [21]. Though, we didn't find any significant differences between the onset of schizophrenia and these physical factors in Pakistani women. The negative symptoms precipitated more in men than in women, however the results remained slightly not significant $(\mathrm{p}=0.06$ ). We proposed that negative symptoms (such as reduction of emotional responsiveness, motivation, socialization, movement, and monosyllabic speech, few gestures, and inability to feel pleasure or act spontaneously) and positive symptoms (such as exaggerations and distortions of normal perception and thinking and hallucinations) are equally precipitated in males and females but more common in men. This could be explained perhaps by the fact that usually men do not like to share their true feelings with their friends or family members. Generally they tend to suppress their emotions which lead to stress and depression and may cause negative symptoms of schizophrenia. However poverty and huge difference between "social classes" are also major issues in Pakistan which induces frustrations leading to mental disorders.

We observed that patients were addicted to tobacco, cannabis, betel nut, and charas. We found that high percentages of males (16.6\%) were using cannabis than tobacco and alcohol and cannabis increases the levels of dopamine in the brain, which can lead to Schizophrenic symptoms [22]. Similarly $25 \%$ of women are addictive to betel nut. Moreover those who were using cannabis under the age of 15 were three times more likely to develop schizophrenia [23]. This is consistent with our study that Pakistani men who use cannabis are having more schizophrenic symptoms as compare to their female counterparts.

\subsection{Association of Transition Metals in the Onset and Progression of Schizophrenia in Pakistani Population}

There is increasing evidence suggesting that the transition metals are essential for many metabolic processes and their homeostasis is crucial for life [24]. In this study we found that Fe levels were decreased in pregnant female patients as compared to male patients leading to more schizophrenic symptoms in married females. This could be explained by the fact that the low availability of iron in plasma results in increased Fe deposition in the brain of the patients [25]. Klinker and colleagues (2011) demonstrated that the Iron deficiency may also decrease dopamine receptors in rats and mice, deregulating spontaneous motor activity and behavior performance during learning exercises [26] [27]. On the other hand excess Fe levels are neurotoxic in adults however results remained not significant [28]. Mn is an essential metal but also have toxic effects [29]. Our results showed an increase in the levels of $\mathrm{Mn}$ in newly and old diagnosed patients which are different from the previous finding that showed a reduced level of $\mathrm{Mn}$ in patients who were on medications [30] but similar to the research [31] showing an association between reduced levels of $\mathrm{Mn}$ in patients taking anti-psychotics medications. We highly recommend follow-ups of the patients using antipsychotic medications. Their Mn levels should be monitored after every three to four months while they are on medicine. On the other hand there is a slight increase in the levels of $\mathrm{Zn}$ and $\mathrm{Cu}$ in newly and old diagnosed male patients as compared to its control healthy siblings. Both of these metals are essential for the development of brain especially $\mathrm{Zn}$ which involves in the neurotransmission of glutamate in the limbic system [32]. Zn is also important for the normal function of enzymes involved in DNA synthesis and repairing such as super oxide dismutase (SOD) and thymidylate synthase [33]. However excess 
copper have significant neurological consequences such as Wilson disease a genetic disorder resembling schizophrenia [34]. There is non-significant increase in the levels of $\mathrm{Pb}$ in our case-control study, care should be taken as lead is a toxic trace metal and its elevated levels have been implicated in schizophrenia [35]. Guilarte et al. (2011) demonstrated that Pb poisoning of mice leads to the expression of mutant forms of DISC-1 gene in Schizophrenic animals. Thus a procedure for decreasing blood $\mathrm{Pb}$ level may be beneficial for the management of schizophrenia. In the present study, elevated levels of $\mathrm{Cr}$ were also observed in newly diagnosed drug-free male schizophrenic patients when compared to male controls, whereas the levels of $\mathrm{Cr}$ were reduced in old diagnosed patients who were on antipsychotic medications. Chromium is an essential trace element that potentiates insulin secretion and enhances the activity of neurotransmitters in the brain. Hence increased levels of $\mathrm{Cr}$ may lead to increased activity of neurotransmitters in the brain, suggesting its role in the pathogenesis of schizophrenia.

Caution should be taken even the levels of $\mathrm{Cr}, \mathrm{Zn}, \mathrm{Mn}$ and $\mathrm{Pb}$ is non-significantly elevated and may make the patients vulnerable to acquire more psychotic symptoms. Importantly it was reported [36] that patients had more depressed mood than controls and siblings but both patients and siblings exhibited a significant increased risk of depressive episodes compared to the controls. In other words siblings have higher chances of meeting lifetime depressive episodes than the controls [36]. Most of the subjects in our study were living in densely populated commercial areas of Karachi, which may increase their risk of having psychotic symptoms in controls as well as subjects with faulty genes.

\section{Acknowledgements}

We would like to acknowledge the financial support from Higher Education Commission (HEC) Islamabad project number 1028, and recurrent grant from PCMD University of Karachi, during this research. We would also like to thanks to the specialist Mr. Felix from The Central Laboratories Unit, Research Affairs, UAE University, for analyzing great number of samples using ICP-OES.

\section{References}

[1] Akhtar, S. (2008) Schizophrenia in Pakistan, The international Society for Psychological and Social Approaches to Psychosis. United States Chapter.

[2] Wright, R.O. and Baccarelli, A. (2007) Metals and Neurotoxicology. The Journal of Nutrition, 137, 2809-2813.

[3] Pachter, J.S., de Vries, H.E. and Fabry, Z. (2003) The Blood-Brain Barrier and Its Role in Immune Privilege in the Central Nervous System. Journal of Neuropathology \& Experimental Neurology, 62, 593-604.

[4] Jomova, K. and Valko, M. (2011) Advances in Metal-Induced Oxidative Stress and Human Disease. Toxicology, 10, 65-87. http://dx.doi.org/10.1016/j.tox.2011.03.001

[5] Önal, S., Nazıroğlu, M., Çolak, M., Bulut, V. and Flores-Arce, M.F. (2011) Effects of Different Medical Treatments on Serum Copper, Selenium and Zinc Levels in Patients with Rheumatoid Arthritis. Biological Trace Element Research, 142, 447-455. http://dx.doi.org/10.1007/s12011-010-8826-7

[6] Dolinoy, D.C., Weidman, J.R. and Jirtle, R.L. (2007) Epigenetic Gene Regulation: Linking Early Developmental Environment to Adult Disease. Reproductive Toxicology, 23, 297-307. http://dx.doi.org/10.1016/j.reprotox.2006.08.012

[7] Bleich, S., Lenzm B., Ziegenbein, M., Beutler, S., Frieling, H., Kornhuber, J. and Bönsch, D. (2006) Epigenetic DNA Hypermethylation of the Herp Gene Promoter Induces Down-Regulation of Its mRNA Expression in Patients with Alcohol Dependence. Alcoholism: Clinical and Experimental Research, 30, 587-591. http://dx.doi.org/10.1111/j.1530-0277.2006.00068.x

[8] Yang, Y., Jing, X.-P., Zhang, S.-P., Gu, R.-X., Tang, F.-X., Wang, X.-L., Xiong, Y., Qiu, M., Sun, X.-Y., Ke, D., Wang, J.-Z. and Liu, R. (2013) High Dose Zinc Supplementation Induces Hippocampal Zinc Deficiency and Memory Impairment with Inhibition of BDNF Signaling. PLOS ONE, 8, 1-9.

http://dx.doi.org/10.1371/journal.pone.0055384

[9] Valerio, F. (2013) Synaptic Physiology Revised: Think Zinc. Future Neurobiology, 7, 433-442.

[10] Brus, R., Jochem, J., Nowak, P., Adwent, M., Boroń, D., Brus, H. and Kostrzewa, R.M. (2012) Effect of Pre- and Postnatal Manganese Exposure on Brain Histamine Content in a Rodent Model of Parkinson's Disease. Neurotoxicity Research, 21, 143-148. http://dx.doi.org/10.1007/s12640-011-9251-1

[11] Barceloux, D.G. (1999) Manganese. Clinical Toxicology, 37, 293-307. http://dx.doi.org/10.1081/CLT-100102427

[12] Canfield, R.L., Henderson, C.R., Cory-Slechta, D.A., Cox, C., Jusko, T.A. and Lanphear, B.P. (2003) Intellectual Impairment in Children with Blood Lead Concentrations below 10 Microgram per Deciliter. New England Journal of Medicine, 348, 1517-1526. http://dx.doi.org/10.1056/NEJMoa022848 
[13] Ercan, O. (2012) Physiopathological Role of Selenium and Selenoprotein in Neuropsychiatric Disease. Journal of Medical Sciences, 11, 11-18.

[14] Tseng, Y.S., Lee, J.C., Huang, C.Y. and Liu, H.S. (2009) Aurora-A Overexpression Enhances Cell-Aggregation of Ha-ras Transformants through the MEK/ERK Signaling Pathway. BMC Cancer, 9, 435. http://dx.doi.org/10.1186/1471-2407-9-435

[15] Chen, Y., Wu, F., Parvez, F., Ahmed, A., Eunus, M., McClintock, T.R., Patwary, T.I., Islam, T., Ghosal, A.K., Islam, S., Hasan, R., Levy, D., Sarwar, G., Slavkovich, V., van Geen, A., Graziano, J.H. and Ahsan, H. (2013) Arsenic Exposure from Drinking Water and QT-Interval Prolongation: Results from the Health Effects of Arsenic Longitudinal Study. Environmental Health Perspectives, 121, 427-432.

[16] Zecca, L., Youdim, M.B., Riederer, P., Connor, J.R. and Crichton, R.R. (2004) Iron, Brain Ageing and Neurodegenerative Disorders. Nature Reviews Neuroscience, 5, 863-873. http://dx.doi.org/10.1038/nrn1537

[17] Massadeh, A., Gharibeh, A., Omari, K., Al-Momani, I., Alomary, A., Tumah, H. and Hayajneh, W. (2010) Simultaneous Determination of $\mathrm{Cd}, \mathrm{Pb}, \mathrm{Cu}, \mathrm{Zn}$, and Se in Human Blood of Jordanian Smokers by ICP-OES. Biological Trace Element Research, 133, 1-11. http://dx.doi.org/10.1007/s12011-009-8405-y

[18] Marrero, J., Rebagliati, R.J., Leiva, E., Londonio, A. and Smichowski, P. (2013) Inductively Coupled Plasma Optical Emission Spectrometric Determination of Fifteen Elements in Dietary Supplements: Are the Concentrations Declared in the Labels Accurate? Microchemical Journal, 108, 81-86. http://dx.doi.org/10.1016/j.microc.2012.12.013

[19] Seeman, M. (2013) Clinical Interventions for Women with Schizophrenia: Pregnancy. Acta Psychiatrica Scandinavica, 127, 12-22. http://dx.doi.org/10.1111/j.1600-0447.2012.01897.x

[20] Pretorius, E. (2011) Corticosteroids, Depression and the Role of Serotonin. Reviews in the Neuroscience, 15, $109-116$.

[21] Gasbarri, A. and Tomaz, C. (2011) Memory and Motivational/Emotional Processes. Behavioral Neuroscience, 6, 71.

[22] Wayne, H. and Louisa, D. (2000) Cannabis Use and Psychosis: A Review of Clinical and Epidemiological Evidence. Australian New Zealand Journal of Psychiatry, 34, 26-34. http://dx.doi.org/10.1046/j.1440-1614.2000.00685.X

[23] Van Gastel, W.A., Wigman, J.T.W., Monshouwer, K., Kahn, R.S., van, O.J., Boks, M.P.M. and Vollebergh, W.A.M. (2012) Cannabis Use and Subclinical Positive Psychotic Experiences in Early Adolescence: Findings from a Dutch Survey. Addiction, 107, 381-387. http://dx.doi.org/10.1111/j.1360-0443.2011.03626.x

[24] Darrah, T.H., Campbell, M.E., Prustman-Pfeiffer, J.J., Poreda, R.J. and Hannigan, R.E. (2013) Chapter 10: Trace Element Composition of Modern Human Bone. In: Censi, P., Darrah, T. and Erel, Y., Eds., Medical Geochemistry, Springer, Dordrecht, 167-191.

[25] Ganz, T. and Nemeth, E. (2012) Iron Metabolism: Interactions with Normal and Disordered Erythropoiesis. Cold Spring Harbor Perspectives in Medicine, 2, 1-13. http://dx.doi.org/10.1101/cshperspect.a011668

[26] Elizabeth, M., Bulent, A., Brianna, B., Evan, W., Ross, G., Roheeth, D., Deborah, T., John, O. and Daniel, J. (2012) Brain Changes in Iron Loading Disorders. Metal Ions in Neurological Systems, 2, 17-29.

[27] Jie Ren, Y.D.W., John, S.Y.C. and Jin, H.Y. (2013) Cognitive Aging Affects Motor Performance and Learning. Geriatrics \& Gerontology International, 13, 19-27. http://dx.doi.org/10.1111/j.1447-0594.2012.00914.X

[28] Stankiewicz, J.M. and Brass, S.D. (2009) Role of Iron in Neurotoxicity: A Cause for Concern in the Elderly? Current Opinion in Clinical Nutrition \& Metabolic Care, 12, 22-29. http://dx.doi.org/10.1097/MCO.0b013e32831ba07c

[29] Colin, B.L., Souza, G.L.M. and Fortoul, T.I. (2011) Toxic Effects of Inhaled Manganese on the Olfactory Bulb: An Ultrastructural Approach in Mice. Journal of Electron Microscopy, 60, 73-78. http://dx.doi.org/10.1093/jmicro/dfq073

[30] Arinola, G., Blessing, I., Kehinde, A. and Olubisi, I. (2010) Essential Trace Metals and Heavy Metals in Newly Diagnosed Schizophrenic Patients and Those on Anti-Psychotic Medication. The Official Journal of Isfahan University of Medical Sciences, 15, 245-249.

[31] Arinola, O. and Idonije, O. (2009) Status of Plasma Nitric Oxide and Non-Enzymatic Antioxidants before and after Antipsychotic Treatment in Nigerian Patients with Schizophrenia. Journal of Research in Medical Science, 14, 37-42.

[32] Ana, M.A., Lucila, A., Maria, P.Z., Carl, L.K., Patricia, I.O., Gerardo, G. and Mackenzie, A.K. (2010) The Role of Zinc in the Modulation of Neuronal Proliferation and Apoptosis. Neurotoxin Research, 17, 1-14. http://dx.doi.org/10.1007/s12640-009-9067-4

[33] Takeda, A. (2001) Zinc Homeostasis and Functions of Zinc in the Brain. Biometals, 14, 343-351. http://dx.doi.org/10.1023/A:1012982123386

[34] Matthew, T.L. (2010) Neurologic Wilson’s Disease. Annals of the New York Academy of Sciences, 1184, $173-187$. http://dx.doi.org/10.1111/j.1749-6632.2009.05109.x

[35] Guilarte, T.R., Opler, M. and Pletnikov, M. (2011) Is Lead Exposure in Early Life an Environmental Risk Factor for Schizophrenia? Neurobiological Connections and Testable Hypotheses. Neurotoxicology, 33, 560-574. 
http://dx.doi.org/10.1016/j.neuro.2011.11.008

[36] Klaassen, R., Heins, M., Luteijn, L., van der Gaag, M. and van Beveren, N. (2013) Depressive Symptoms Are Associated with (Sub)clinical Psychotic Symptoms in Patients with Non-Affective Psychotic Disorder, Siblings and Healthy Controls. Psychological Medicine, 1, 1-10.kl 
Scientific Research Publishing (SCIRP) is one of the largest Open Access journal publishers. It is currently publishing more than 200 open access, online, peer-reviewed journals covering a wide range of academic disciplines. SCIRP serves the worldwide academic communities and contributes to the progress and application of science with its publication.

Other selected journals from SCIRP are listed as below. Submit your manuscript to us via either submit@scirp.org or Online Submission Portal.
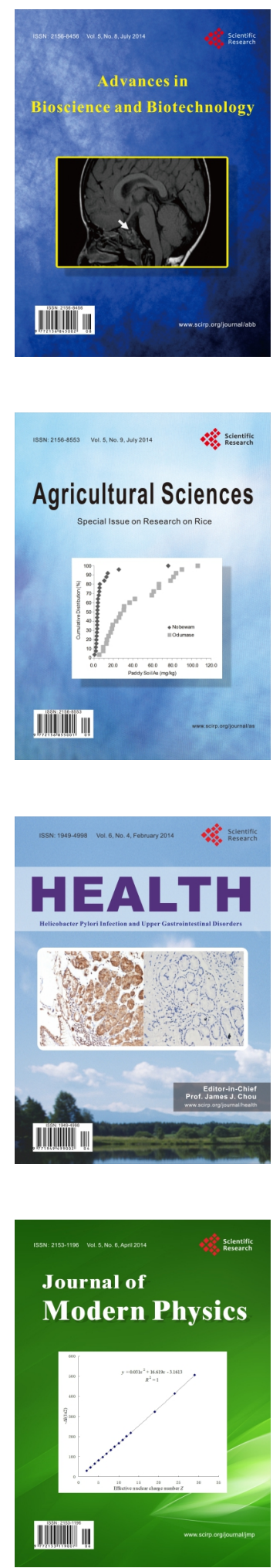
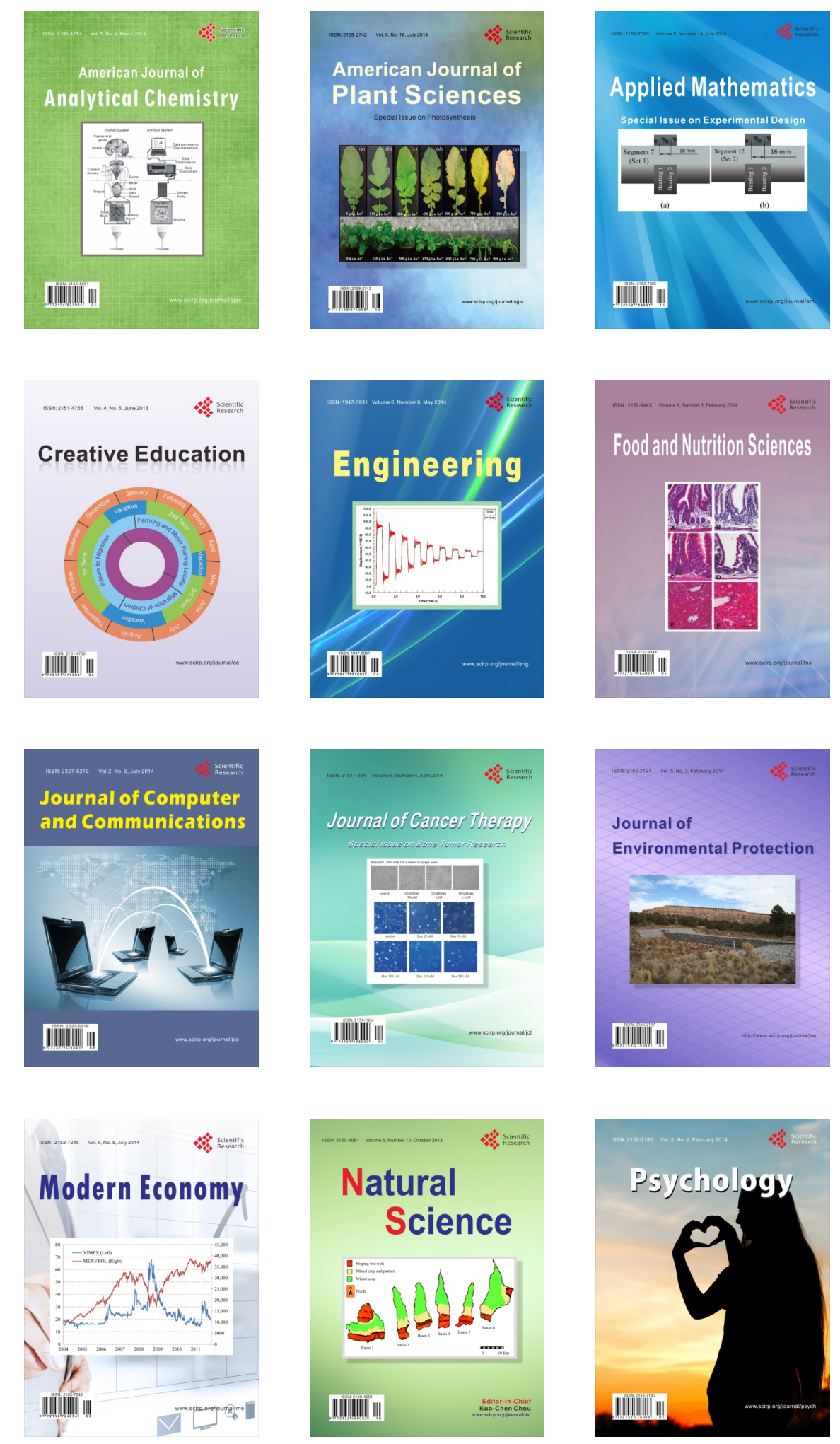